\title{
Identifikasi Kualitas Air dan Beban Pencemaran Sungai Bedadung di Intake Instalasi Pengolahan Air PDAM Kabupaten Jember
}

\author{
Hendra Andiananta Pradana ${ }^{1}$, Sri Wahyuningsih ${ }^{2 *}$, Elida Novita ${ }^{2}$, Aisyah Humayro ${ }^{2}$, \\ Bambang Herry Purnomo \\ ${ }^{1}$ Magister Pengelolaan Sumber Daya Air Pertanian Univeristas Jember \\ ${ }^{2}$ Fakultas Teknologi Pertanian Universitas Jember \\ *Coresponding author: sriwahyuningsih.ftp@unej.ac.id
}

Info Artikel : Diterima Agustus 2019 ; Disetujui September 2019 ; Publikasi Oktober 2019

\begin{abstract}
ABSTRAK
Latar belakang: Salah satu sumber air permukaan yang memiliki peran vital bagi ekosistem perairan dan makhluk hidup adalah sungai. Sungai Bedadung merupakan salah satu sungai besar yang melewati wilayah Perkotaan Kabupaten Jember. Air dari sungai tersebut dimanfaatkan sebagai pemasok air baku untuk PDAM Kabupaten Jember. Akan tetapi akibat tekanan aktivitas antropogenik menurunkan kualitas air sungai tersebut. Pemantauan kualitas air diperlukan sebagai salah satu pertimbangan pengendalian pencemaran pada air sungai tersebut. Tujuan penelitian ini mengidentifikasi kondisi kualitas air dan beban pencemaran di intake intalasi pengolahan air (IPA) PDAM Kabupaten Jember.

Metode: Pengambilan contoh air secara grab sampling dilakukan di intake IPA Tegal Gede dan IPA Tegal Besar dengan beberapa parameter kualitas air yang diamati yaitu suhu, kekeruhan, TDS, pH, DO, BOD, COD, yang dibandingkan dengan baku mutu Peraturan Pemerintah Republik Indonesia Nomor 82 tahun 2001 serta debit air yang digunakan untuk menghitung beban pencemaran serta dilanjutkan uji t untuk mengetahui perbandingan kondisi beban pencemaran.

Hasil: Hasil penelitian menjabarkan bahwa kualitas air sungai di intake IPA Tegal Gede dan IPA Tegal Besar secara berurutan tergolong kelas I dan III. Nilai COD di intake IPA Tegal Besar tergolong kelas III. Nilai beban pencemaran menujukkan perbedaan yang signifikan pada kedua intake IPA. Beban pencamaran di IPA Tegal Gede dan Tegal Besar dengan nilai rata-rata secara berurutan yaitu 24,96 kg/hari dan 74,03 kg/hari.

Simpulan: Kualitas air Sungai Bedadung berdasarkan parameter fisika dan kimia di intake IPA Tegal Gede di IPA Tegal Besar secara berurutan tergolong kelas I dan III serta kondisi beban pencemaranya beragam.
\end{abstract}

Kata kunci: parameter fisika-kimia; beban pencemaran; sungai; baku mutu

\section{ABSTRACT}

Title: Identification of the Water Quality and Pollution Load Bedadung River in Water Treatment Plants Intake of Jember Regency Municipal Waterworks

Background: River as one of surface water resource has a vital role for ecosystems and organism. Jember Regency Municipal Waterworks utilized the river as water raw resources. However, the anthropogenic activities impacted water quality decline in the river. Water quality monitoring was needed as a consideration for pollution controlling in the river. The focus research investigated water quality and pollution load in the water treatment plants (WTP) intake of Jember Regency Municipal Waterworkers.

Methods: Water sampling by grab sampling was carried out he intake of Tegal Gede and Tegal Besar WTP with observed pysicochemical parameters i.e temperature, turbidity, TDS, pH, DO, BOD, COD compered with Government Regulation No.82 of 2001 and stream flow for pollution load measurement and continued by t-test to compire the pollution load conditions.

Results: The water quality refer to physicochemical parameter in intake of Tegal Gede and Tegal Besar WTP respectively including I and III standard. COD caused water quality decline in intake of Tegal Besar WTP. The t-test of the pollution load represented a significantly difference at the both water treatment plants locations. 
The evenly of pollution load in the Tegal Gede and Tegal Besar WTP respectively were $24.96 \mathrm{~kg} /$ day and 74.03 $\mathrm{kg} /$ day.

Conclusion: The water quality refer to physicochemical parameter in intake of Tegal Gede and Tegal Besar WTP respectively including I and III standard and had the pollution load diverse.

Keywords: physicochemical parameters; pollution load; river; standard

\section{PENDAHULUAN}

Air adalah kebutuhan dasar untuk kehidupan manusia. Indonesia merupakan wilayah yang memiliki potensi sumber air permukaan sebesar $6 \%$ dari seluruh sumber air tawar di Dunia. Akan tetapi pencemaran pada beberapa sungai besar di Indonesia seperti Sungai Musi, Citarum, Ciliwung, dan Brantas status airnya tercema. ${ }^{1,33}$

Berdasarkan Peraturan Kementerian Lingkungan Hidup Nomor 1 Tahun 2010 tentang Tata Laksana Pengendalian Pencemaran Lingkungan seperti program kali bersih ${ }^{2}$. Meskipun kebijakan tersebut sudah ditetapkan hasilnya kurang maksimal. Sejalan dengan hal tersebut berdasarkan laporan dari Pusat Data dan Informasi Kementerian Lingkungan Hidup Republik Indonesia indeks kualitas air nasional cenderung menurun dari tahun 2013 hingga 2017. ${ }^{3}$

Fenomena pencemaran sumber air akan berisiko pada akses sumber air bersih dan berdampak pada pengolahan air bersih oleh Perusahaan Daerah Air Minum (PDAM). Sejalan dengan fenomena ini, peningkatan pencemaran air pada Sungai Surabaya di Jawa Timur disebabkan oleh tingginya kandungan bahan organik ${ }^{34}$. Kondisi tersebut berpotensi meningkatkan biaya operasional pula berdasarkan studi yang dilakukan oleh Kusumawardani. ${ }^{4}$ Konsekuensi peningkatan biaya operasional akibat peningkatan pencemaran sungai berpotensi terjadi pada PDAM di Indonesia.

Kabupaten Jember merupakan salah satu daerah yang memiliki PDAM dengan 4 Instalasi Pengolahan Air (IPA). Kebutuhan air bersih khusus di Kota Jember mendapat pasokan dari dua IPA yaitu IPA Tegal Gede dan Tegal Besar. IPA Tegal Gede terletak di Kelurahan Tegal Gede dengan kondisi lingkungan yang didominasi oleh lahan pertanian dan pemukiman. ${ }^{5}$ IPA Tegal Besar terletak di Kelurahan Tegal Besar dengan kondisi lingkungan yang didominasi oleh perumahan warga. ${ }^{6}$

Kebutuhan air di kedua IPA tersebut dipenuhi oleh sumber baku air bersih dari air Sungai Bedadung. Menurut Balai Pengelolaan Sumberdaya Air Wilayah Sungai (BPSAWS) Bondoyudo-Mayang, kualitas air Sungai Bedadung masuk ke dalam kriteria baku mutu air kelas III dan dalam status tercemar berat pada segmen Perkotaan Kabupaten Jember. ${ }^{9}$ Berdasarkan laporan dari Dinas Lingkungan Hidup Provinsi Jawa Timur (2017) serta Munandar dan Eurika (2016) menujukkan status air Sungai Bedadung dalam kategori sangat kurang dan memiliki kandungan mikroorganisme patogen serta bahan organik (COD dan BOD) yang tinggi. ${ }^{10,11}$ Sementara kualitas sumber air baku air minum harus memenuhi baku mutu air kelas I dengan merujuk pada Peraturan Pemerintah Nomor 82 Tahun 2001 Tentang Pengelolaan Kualitas Air dan Pengendalian Pencemaran Air dan Peraturan Daerah Provinsi Jawa Timur Nomor 02 Tahun 2008 Tentang Pengelolaan Kualitas Air dan Pengendalian Pencemaran Air di Provinsi Jawa Timur. ${ }^{7,8}$

Sumber-sumber yang menyebabkan terjadinya pencemaran air sungai dan peningkatan beban pencemaran, antara lain limbah industri, limbah rumah tangga dan limbah pertanian. ${ }^{12,13,35}$. Selain bahan pencemar, perubahan cuaca dan tata guna lahan turut mempengaruhi kualitas air sungai dan beban pencemaran. ${ }^{6,14,15,16}$ Pemantauan kualitas air dan beban pencemaran menjadi pertimbangan dalam pengendalian pencemaran sungai berdasarkan Keputusan Menteri Lingkungan Hidup Nomor 110 dan 115 tentang Penentapan Daya Tampung Beban Pencemaran dan Penetapan Status Mutu Air. ${ }^{17,18,20}$ Tujuan penelitian ini adalah mengidentifikasi kondisi kualitas air dan beban pencemaran di intake intalasi pengolahan air (IPA) di Tegal Gede dan Tegal Besar PDAM Kabupaten Jember sebagai pertimbangan pengendalian pencemaran Sungai Bedadung dan rekomendasi pengambilan serta pengolahan air baku bagi PDAM Kabupaten Jember.

\section{MATERI DAN METODE}

Penelitian ini dilakukan di Sungai Bedadung utama yang digunakan sebagai intake PDAM Kabupaten Jember. IPA Tegal Gede berada di upstream dan IPA Tegas Besar berada di downstream. Pengambilan contoh air dan debit air dilakukan secara grab sampling atau pengambilan secara sesaat. ${ }^{5}$ Penelitian ini dilakukan pada bulan Oktober 2017. Penentuan jarak pengambilan contoh air dilakukan pada jarak $1 \mathrm{~km}$ sebelum intake IPA Tegal Gede (titik 1) dan IPA TegaL Besar (titik 2). Penentuan jarak ini bertujuan untuk mengetahui karakteristik air sungai dan beban pencemaran yang sudah diasumsikan sudah tercampur sempurna (homogen) sebelum masuk sebagai input di kedua IPA. ${ }^{36}$ Lokasi penelitian dan pengambilan contoh air dapat dilihat pada gambar 1 dan 2 . Tahapan penelitian yang dilaksanakan dijabarkan berikut ini.

1. Identifikasi sumber pencemaran di sekitar IPA PDAM Kabupaten Jember dilakukan berdasarkan peta tata guna lahan yang dapat dilihat pada gambar 3. 


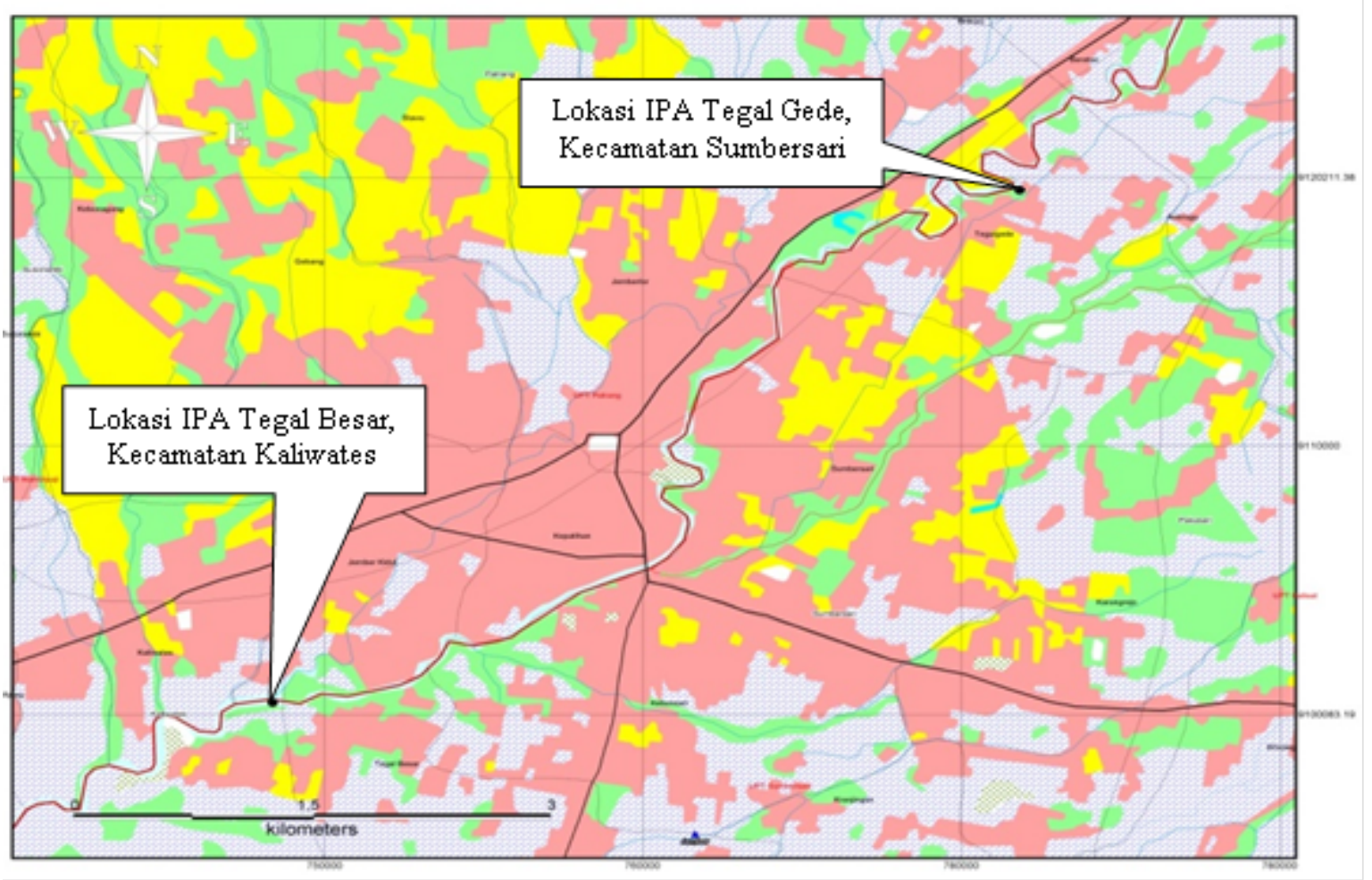

Gambar 1. Lokasi penelitian

2. Pengukuran di lapangan meliputi parameter suhu sedangkan pengukuran di Laboratorium Teknik Pengendalian dan Kanservasi Lingkungan Jurusan Teknik Pertanian Universitas Jember meliputi parameter kekeruhan, TDS, $\mathrm{pH}, \mathrm{DO}, \mathrm{BOD}$ dan COD. Parameter tersebut dapat menjadi parameter kunci jika terjadi pencemaran pada air sungai berdasarkan Keputusan Menteri Lingkungan
Hidup Nomor 1 tahun 2010 tentang Tata Laksana Pengendalian Pencemaran. ${ }^{2}$ Pengukuran nilai paremeter fisika-kimia kualitas air dilakukan pada pukul 07.00 (pagi); 11.30 (siang); dan 16.00 (sore) WIB dan pengulangan 3 kali. Pemilihan waktu tersebut berdasarkan aktivitas puncak dari aktivitas antropogenik. ${ }^{36}$ Adapun analisis pengukuran tiap parameter berikut ini.

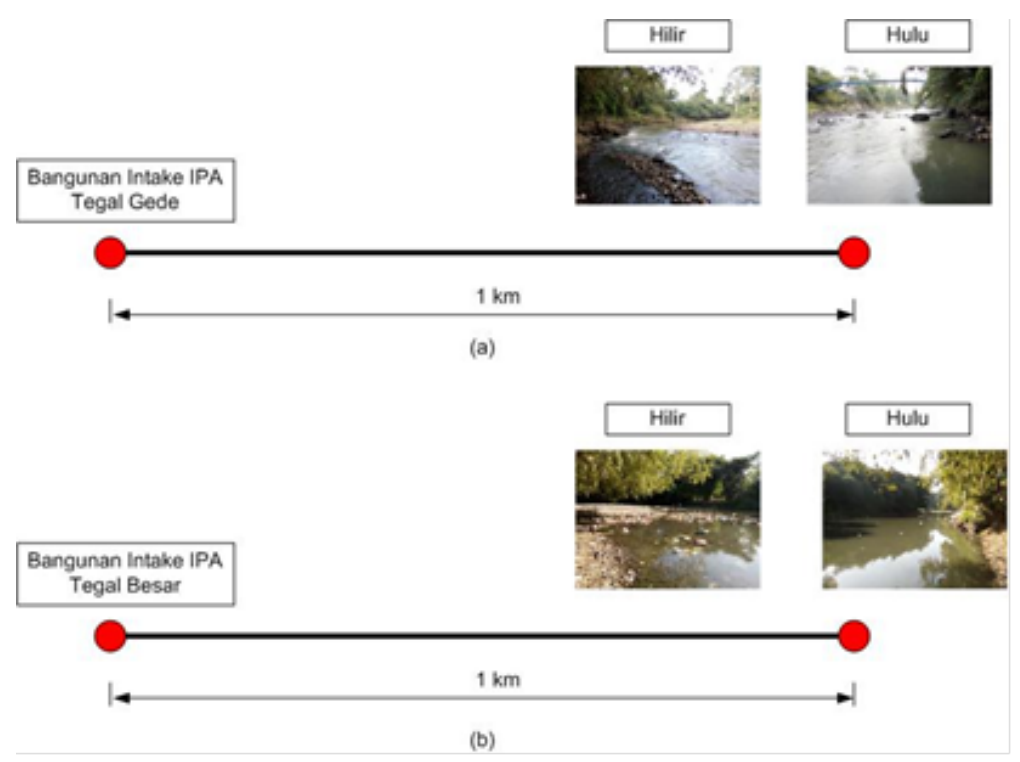

Gambar 2. Lokasi pengambilan contoh air di intake IPA Tegal Gede dan Tegal Besar 
a. Pengukuran suhu dilakukan di lapangan menggunakan termometer.

b. Pengukuran kekeruhan menggunakan turbiditymeter di laboratorium.

c. Pengukuran Total Dissolved Solid (TDS) menggunakan TDSmeter di laboratorium.

d. Pengukuran $\mathrm{pH}$ atau tingkat derajat keasaman air menggunakan pHmeter di laboratorium.

e. Identifikasi nilai Dissolved Oxygen (DO) diukur menggunakan metode winkler. Rujukan perhitungan ini berdasarkan Standar Nasional Indonesia (SNI) 6989.72:2009. Persamaan yang digunakan dalam menyelidiki nilai DO dapat dilihat pada persamaan 1 .

$\mathrm{DO}=\frac{\text { Q.N.8000 }}{\square-4}$

Keterangan :

$\mathrm{DO}=$ oksigen terlarut $\left(\mathrm{mgO}_{2} / \mathrm{L}\right)$

a $\quad=$ volume titran $(\mathrm{mL})$

$\mathrm{N} \quad=$ normalitas larutan natrium $(\mathrm{ek} / \mathrm{L})$

$\mathrm{V}=$ volume botol Winkler $(\mathrm{mL})$

f. Nilai Biochemical Oxygen Demand (BOD) dapat diketahui berdasarkan metode winkler. Rujukan perhitungan ini berdasarkan Standar Nasional Indonesia (SNI) 6989.72:2009. Persamaan yang digunakan dalam menyelidiki nilai DO dapat dilihat pada persamaan 2 .

$$
B O D_{5}^{20}=\frac{\left(X_{0}-X_{5}\right)-\left(B_{0}-B_{5}\right)(1-P)}{P}
$$

Keterangan :

$$
\begin{array}{ll}
\mathrm{X}_{0} & =\text { DO contoh } \mathrm{t}=0\left(\mathrm{mg} \mathrm{O}_{2} / \mathrm{L}\right) \\
\mathrm{X}_{5} & =\text { DO contoh } \mathrm{t}=5\left(\mathrm{mg} \mathrm{O}_{2} / \mathrm{L}\right) \\
\mathrm{B}_{0} & =\text { DO blanko } \mathrm{t}=0\left(\mathrm{mg} \mathrm{O}_{2} / \mathrm{L}\right) \\
\mathrm{B}_{5} & =\text { DO blanko } \mathrm{t}=5 \text { hari }\left(\mathrm{mg} \mathrm{O}_{2} / \mathrm{L}\right) \\
\mathrm{P} & =\text { Derajat pengenceran }
\end{array}
$$

g. Spektrofometri salah satu metode yang dapat digunakan untuk mengidenfikasi nilai Chemical Oxygen Demand (COD). Rujukan perhitungan ini berdasarkan Standar Nasional Indonesia (SNI) 6989.2:2009. Prosedur pengukuran yaitu (1) dimasukkan contoh air sejumlah 0,2 mL ke dalam reagen High Range (HR) dan dipanaskan menggunakan pada

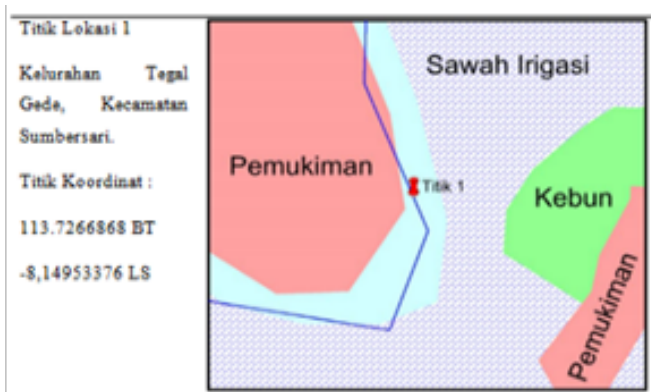

(a) Titik 1 (Intake IPA Tegal Gede) reaktor COD selama 2 jam, (2) reagen didinginkan hingga mencapai suhu ruang dan dilakukan pembacaan pada spektrofometer.

h. Pengukuran kecepatan aliran air dan luas penampang sungai merupakan data input untuk menghitung debit air sungai. Pengkuran kecepatan aliran menggunakan currentmeter pada masing-masing pias yang sudah ditentukan. Kriteria pengukuran kecepatan aliran merujuk pada tabel 1 dan persamaan 3 . Pengukuran debit air merujuk pada Standar Nasional Indonesia (SNI) 8066:2015.

Tabel 1. Posisi titik ketinggian pengukuran aliran

\begin{tabular}{ccc}
\hline $\begin{array}{c}\text { Kedalaman } \\
\text { Air }(\mathbf{m})\end{array}$ & $\begin{array}{c}\text { Titik } \\
\text { Pengukuran }\end{array}$ & $\begin{array}{c}\text { Kecepatan Rata- } \\
\text { Rata (m/detik) }\end{array}$ \\
\hline$<0.6$ & $0.6 \mathrm{~d}$ & $\mathrm{~V} 0.6$ \\
$0.6-3.0$ & $0.2 \mathrm{~d} ; 0.8 \mathrm{~d}$ & $(\mathrm{~V} 0.2 \mathrm{~d}+\mathrm{V} 0.8 \mathrm{~d}) / 2$ \\
$3.0-0.6$ & $0.2 \mathrm{~d} ; 0.6 \mathrm{~d} ;$ & $(\mathrm{V} 0.2 \mathrm{~d}+\mathrm{V} 0.6 \mathrm{~d}+$ \\
& $0.8 \mathrm{~d}$ & $\mathrm{~V} 0.8 \mathrm{~d}) / 4$ \\
\hline
\end{tabular}

(Sumber: Aziza dkk. 2018)

$$
\mathrm{Q} \quad=\mathrm{V} . \mathrm{A}
$$

Keterangan:

$\mathrm{Q}=$ Debit pada titik ke-n $\left(\mathrm{m}^{3} /\right.$ detik $)$

$\mathrm{V}=$ Kecepatan aliran $(\mathrm{m} /$ detik $)$

A $=$ Luas penampang $(\mathrm{m})$

i. Penentuan nilai beban pencemaran diperoleh dari perkalian antara debit air dan konsentrasi BOD yang dapat dilihat pada persamaan $4 .^{17}$ $\mathrm{L}=\mathrm{Q} \times \mathrm{C}$

Keterangan:

$$
\begin{array}{ll}
\mathrm{L} & =\text { Beban pencemaran }(\mathrm{kg} / \mathrm{hari}) \\
\mathrm{Q} & =\text { Debit air sungai }\left(\mathrm{m}^{3} / \text { detik }\right) \\
\mathrm{C} & =\text { Konsentrasi parameter }(\mathrm{mg} / \mathrm{L})
\end{array}
$$

Data beban pencemaran di Sungai Bedadung yang menjadi masukan di masing-masing IPA akan dibandingkan untuk mengetahui perbedaan antara kondisi beban pencemaran yang dihadapi IPA Tegal Gede dan Tegal Besar menggunakan uji $t$ dengan menggunakan software SPSS 15.0. Pada output penelitian ini diharapkan dapat menjadi informasi dan pertimbangan terkait pengendalian pencemaran sungai dan pengolahan air di PDAM, khususnya di IPA Tegal Gede dan Tegal Besar.

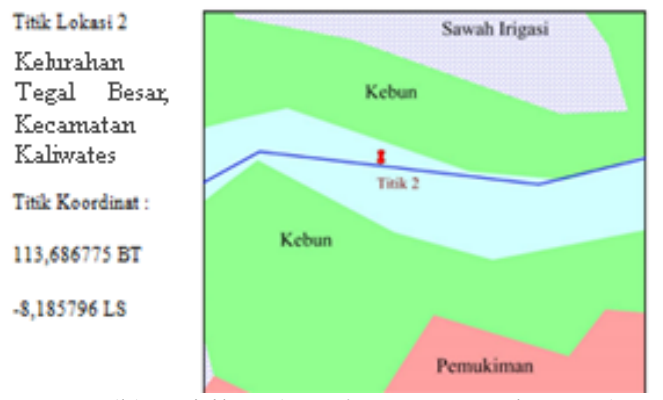

(b) Titik 2 (Intake IPA Tegal Besar)

Gambar 3. Tata guna lahan di sekitar intake PDAM Kabupaten Jember 
HASIL DAN PEMBAHASAN

\section{Analisis Kualitas Air di Sekitar Intake IPA Tegal Gede dan IPA Tegal Besar}

Kualitas air di intake PDAM Kabupaten Jember memiliki nilai yang beragam. Secara umum kualitas air di intake Tegal Gede berdasarkan parameter fisika dan kimia air sungai tersebut tidak melebihi baku mutu kelas I menurut Peraturan Pemerintah Republik Indonesia Nomor 82 Tahun 2001 tentang Pengelolaan
Kualitas Air dan Pengendalian Pencemaran Air. Baku mutu kelas I berpotensi layak dimanfaatkan sebagai sumber air baku. Namun nilai COD pada intake Tegal Besar tergolong kelas III. Oleh sebab itu kualitas air di intake tersebut tergolong kelas III meskipun parameter lainnya tergolong kelas I. Hasil pemeriksaan kualitas air dapat dilihat pada tabel 2 . Hasil pemeriksaan parameter kualitas air baik parameter fisika dan kimia memiliki perbedaan.

Tabel 2. Hasil Pemeriksaan Kualitas air di intake IPA Tegal Gede dan Tegal Besar

\begin{tabular}{|c|c|c|c|c|c|c|c|c|c|}
\hline \multirow{2}{*}{ Parameter } & \multirow{2}{*}{ Satuan } & \multirow{2}{*}{ Kelas I } & \multirow{2}{*}{$\begin{array}{l}\text { Kelas } \\
\text { III }\end{array}$} & \multicolumn{3}{|c|}{$\begin{array}{c}\text { Nilai Rata-Rata di IPA } \\
\text { Tegal Gede }\end{array}$} & \multicolumn{3}{|c|}{$\begin{array}{c}\text { Nilai Rata-Rata di IPA Tegal } \\
\text { Besar }\end{array}$} \\
\hline & & & & Pagi & Siang & Sore & Pagi & Siang & Sore \\
\hline Suhu & & Deviasi 3 & Deviasi 3 & 26,22 & 28,22 & 30,67 & 25,50 & 32,17 & 30,72 \\
\hline Kekeruhan & NTU & - & - & 12,13 & 12,55 & 12,46 & 3,11 & 3,38 & 3,67 \\
\hline TDS & $\mathrm{mg} / \mathrm{L}$ & 1000 & 1000 & 156,44 & 156,11 & 157,22 & 181,11 & 176,89 & 181,56 \\
\hline $\mathrm{pH}$ & - & $6-9$ & $6-9$ & 7,40 & 7,74 & 7,90 & 7,30 & 7,42 & 7,48 \\
\hline BOD & $\mathrm{mg} / \mathrm{L}$ & 2,00 & 6,00 & 0,75 & 1,13 & 0,78 & 1,45 & 1,87 & 1,67 \\
\hline COD & $\mathrm{mg} / \mathrm{L}$ & 10,00 & 50,00 & 9,00 & 7,00 & 7,00 & 23,00 & 25,00 & 30,00 \\
\hline DO & $\mathrm{mg} / \mathrm{L}$ & 6,00 & 3,00 & 8,77 & 7,14 & 8,00 & 7,17 & 6,00 & 7,15 \\
\hline
\end{tabular}

1. Karakteristik Kualitas Air IPA Tegal Gede

Hasil analisis kualitas air pada Titik 1 (IPA Tegal Gede) didapatkan nilai suhu, kekeruhan, dan TDS yang relatif seragam pada setiap pengamatan. Nilai rata-rata suhu, kekeruhan, dan TDS secara berurutan yaitu $28,37^{\circ} \mathrm{C} ; 12,36 \mathrm{mg} / \mathrm{L}$; dan 156,59 $\mathrm{mg} / \mathrm{L}$. Suhu perairan pada titik ini cenderung normal dan menjadi ciri khas suhu perairan wilayah tropis. ${ }^{19}$ Nilai kekeruhan cenderung rendah sehingga halangan matahari mengenai perairan tidak besar. Nilai kekeruhan yang rendah mengindikasikan rendahnya padatan yang melayang pada badan air dan rendahnya jumlah alga. ${ }^{30}$ Banyaknya padatan terlarut atau TDS yang berukuran $>1 \mathrm{~nm}$ relatif rendah. TDS merupakan parameter kualitas air yang munujukkan kandungan mineral dan bentuk ion bebas seperti $\mathrm{Na}, \mathrm{Ca}$ dan $\mathrm{Mg}$. Jika nilai TDS tinggi maka tidak layak dimanfaatkan sebagai sumbai sumber air baku karena menimbulkan risiko gangguan kesehatan bila digunakan sebagai sumber air bersih. ${ }^{21,32}$

Parameter kimia yang terdiri atas $\mathrm{pH}, \mathrm{DO}, \mathrm{BOD}$, dan COD memilki nilai yang beragam. Nilai rata-rata parameter $\mathrm{pH}$, DO, BOD, dan COD secara berurutan yaitu 7,68; 7,97 mg/L; 0,87 mg/L; dan 7,67 mg/L. pH di sekitar Intake IPA Tege Gede relatif netral karena masih dalam rentang nilai 7-9. Jika nilai $\mathrm{pH}$ diluar rentang nilai tersebut dapat mengancam kelangsungan hidup organisme. Nilai $\mathrm{pH}$ yang rendah dapat mengancam ekosistem perairan dan pertumbuhan ikan air tawar. ${ }^{20}$ Oksigen terlarut diindikasikan oleh nilai DO. Nilai DO relatif tinggi di titik 1. Tingginya nilai DO diperngaruhi oleh profil sungai. Hasil penelitian
Pradana tahun 2018, menjabarkan bahwa Sungai Bedadung segmen Kecamatan Patrang-Sumbersari memiliki memiliki profil sungai dan kecepatan aliran yang beragam ${ }^{5}$. Kondisi ini mendukung pembentukan turbulensi dan memudahkan tranfer oksigen dari atas perairan ke dalam badan air. Disisi lain jika nilai DO tinggi akan mempengaruhi reduksi bahan organik mudah terurai yang diindikasikan oleh nilai BOD dan COD. Nilai kedua parameter tersebut juga dipengaruhi oleh aktivitas domestik dan industri. Rendahnya nilai BOD dan COD di titik 1 mengindikasikan tingkat pencemaran oleh sumber pencemar relatif rendah. ${ }^{5,20}$

2. Karakteristik IPA Kualitas Air di Sekitar IPA Tegal Besar

Hasil analisis kualitas air pada Titik 2 (IPA tegal Gede) didapatkan nilai suhu, kekeruhan, dan TDS yang relatif seragam pada setiap pengamatan. Nilai rata-rata suhu, kekeruhan, dan TDS secara berurutan yaitu $29,46^{\circ} \mathrm{C} ; \quad 3,39 \mathrm{mg} / \mathrm{L} ;$ dan $179,85 \mathrm{mg} / \mathrm{L}$. Kekeruhan relatif rendah sehingga di sekitar intake ini kondisi kejernihan airnya tinggi. Kondisi ini mendukung penyediaan oksigen oleh aktivitas fotosintesis pada badan air. ${ }^{22}$

Parameter kimia yang terdiri atas $\mathrm{pH}, \mathrm{DO}, \mathrm{BOD}$, dan COD memiliki nilai yang beragam. Nilai rata-rata parameter $\mathrm{pH}, \mathrm{DO}, \mathrm{BOD}$, dan COD secara berurutan yaitu 7,4; 6,44 mg/L; 1,66 mg/L; dan $26 \mathrm{mg} / \mathrm{L}$. Parameter COD melebihi baku mutu kelas I. Peningkatan nilai parameter COD ini dipengaruhi oleh akumulasi bahan organik dan cemaran senyawa kimia dari indutri. Sebagai pembanding studi industri 
batik dan laundry yang membuang limbahnya ke sungai mampu meningkatan nilai COD hingga mencapai $500 \mathrm{mg} / \mathrm{L}^{22,35}$ Aktivitas domestik mampu meningkatan nilai COD Sungai Code hingga mencapai $100 \mathrm{mg} / \mathrm{L}$ berdasarkan penyelidikan oleh Widodo di tahun 2013. ${ }^{23}$ Perbedaan kondisi kualitas air di kedua IPA dipengaruhi oleh akumulasi bahan pencemar. Nilai parameter fisika dan kimia di IPA Tegal Besar juga dipengaruhi oleh akumulasi dari Sungai Antirogo dan Kalijompo yang bermuara di Kecamatan Sumbersari.

Pengelolaan dan pengendalian pencemaran air sungai harus tetap dilakukan meskipun fungsi alamiahnya dalam kondisi baik. Sungai Bedadung yang melintasi Kecamatan Sumbersari dan Kaliwates berpotensi mengalami tekanan pencemaran yang tinggi mengingat Rencana Tata Raung Wilayah (RTRW) tahun 2015 kedua kecamatan tersebut termasuk wilayah Perkotaan Kabupaten Jember. Penyelidikan oleh Evan di tahun 2012 menujukkan bahwa lemahnya aplikasi manajemen kualitas lingkungan di beberapa negara berkembang di Benua Asia berisiko meningkatan pencemaran pada sumber daya air. ${ }^{24}$ Oleh sebab itu diperlukan upaa pencegahan dari pencemaran yang akan timbul ang diakibatkan olek aktivitas antropogenik atau proses alam. Adapun beberapa strategi pengendalian pencemaran sungai yaitu pembangunan Instalasi Pengolahan Air Limbah (IPAL) komunal, perbaikan sanitasi lingkungan, peningkatan peran masyarakat dan stakeholder, serta penguatan kelembagaan. ${ }^{25,26,28}$

\section{Analsis Beban Pencemaran}

Nilai beban pencemaran dipengaruhi oleh besarnya debit aliran sungai dan zat pencemar yang terkandung dalam aliran sungai dalam hal ini adalah konsentrasi DO dan BOD. Hasil penyelidikan Pradana dan Aziza analisis beban pencemaran di sekitar
Sungai Bedadung Utama dan anak sungainya berasal dari sumber pencemar non-point source sehingga pengukuran pencemaran pada penelitian dilakukan langsung pada aliran sungai, dengan asumsi seluruh zat pencemar yang berasal dari sumber pencemar domestik, pertanian maupun industri telah tercampur merata di dalam aliran air sungai. ${ }^{5,6,36}$

Nilai beban pencemaran tertinggi di kedua titik pada hari pertama hingga ketiga rata-rata terjadi pada siang hari pukul 11.30 WIB dengan nilai 30,23 $\mathrm{kg} /$ hari di titik 1 dan $77,90 \mathrm{~kg} /$ hari di titik 2 . Hal tersebut disebabkan oleh nilai BOD yang dihasilkan pada titik 2 lebih tinggi dari titik 1. Kenaikan konsentrasi BOD tersebut dapat disebabkan oleh kondisi tata guna lahan dan aktivitas masyarakat. Kondisi tata guna lahan pada setiap lokasi dapat disajikan pada gambar 4. Banyaknya aktivitas masyarakat seperti mandi, buang air besar, mencuci pakaian bahkan membuang sampah secara langsung ke badan sungai. Besarnya nilai BOD tersebut dapat mempengaruhi jumlah beban pencemaran yang terjadi di badan air. ${ }^{34,37}$

Debit sungai juga akan mempengaruhi nilai beban pencemaran. Semakin tinggi debit yang dihasilkan maka beban pencemaran yang terjadi juga semakin tinggi. Pada titik 2, debit yang dihasilkan adalah 501,6 - 570,25 L/s lebih besar bila dibandingkan debit pada titik 1 adalah 310,56-339,77 L/s. Debit pada titik 2 bertambah karena sebelumnya juga telah mendapat masukan dari Sungai Antirogo. Secara teoritis parameter debit dan konsentrasi BOD saling mempengaruhi terjadinya kenaikan beban pencemaran. Sejalan dengan kondisi ini hasil kajian yang dilakukan oleh Liu dkk. (2016) water level yang berimplikasi dengan debit air memiliki hubungan kuat terhadap peningkatan nilai distribusi bahan organik pada badan air. ${ }^{30}$

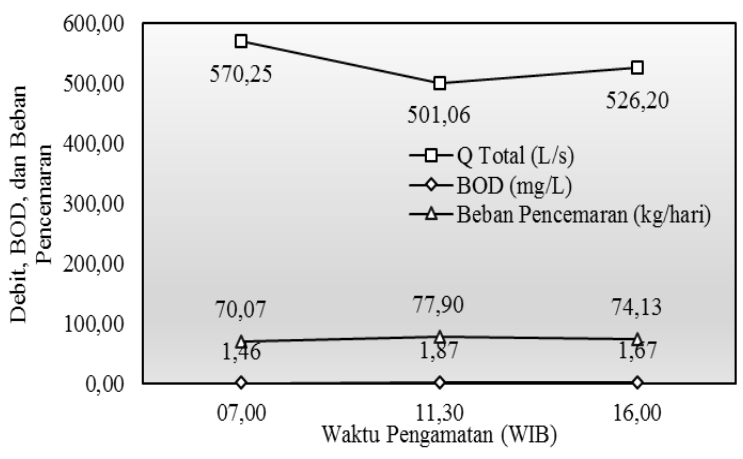

(b) IPA Tegal Besar

Gambar 4. Hasil pemeriksaan debit, BOD, dan beban pencemaran di kedua IPA PDAM

Titik 2 memiliki nilai rata-rata beban pencemaran yang lebih tinggi dari titik 1. Hasil pemantauan beban pencemaran di IPA Tegal Gede dan Tegal Besar dapat dilihat pada gambar 5. Nilai rata-rata beban pencemaran pada IPA tegal Gede dan Tegal Besar secara berurutan yaitu $24,97 \mathrm{~kg} /$ hari dan $74,03 \mathrm{~kg} /$ hari. Fakta empiris ini didukung dengan uji statistika. Pada uji normalitas dihasilkan nilai Sig uji 
Shapiro Wilk pada Titik 1 sebesar 0,091 > 0,05 dan pada Titik 2 sebesar $0,526>0,05$. Karena semua $>$ 0,05 maka kedua kelompok sama-sama berdistribusi normal berdasarkan uji Shapiro Wilk. Setelah diketahui bahwa data tersebut berdistribusi normal, barulah dapat dilanjutkan untuk melakukan uji beda menggunakan metode uji t. Diketahui bahwa nilai t hitung data nilai beban pencemaran adalah 16,585 dengan jumlah 18 data diperoleh $\mathrm{df}=16$, serta nilai signifikansi $\alpha=0.05(5 \%)$ maka diperoleh nilai t tabel $=2,11991$. Oleh karena itu disimpulkan bahwa nilai t hitung lebih besar dari t tabel maka terdapat perbedaan yang signifikan antara beban pencemaran yang ada di titik 1 dengan titik 2 .

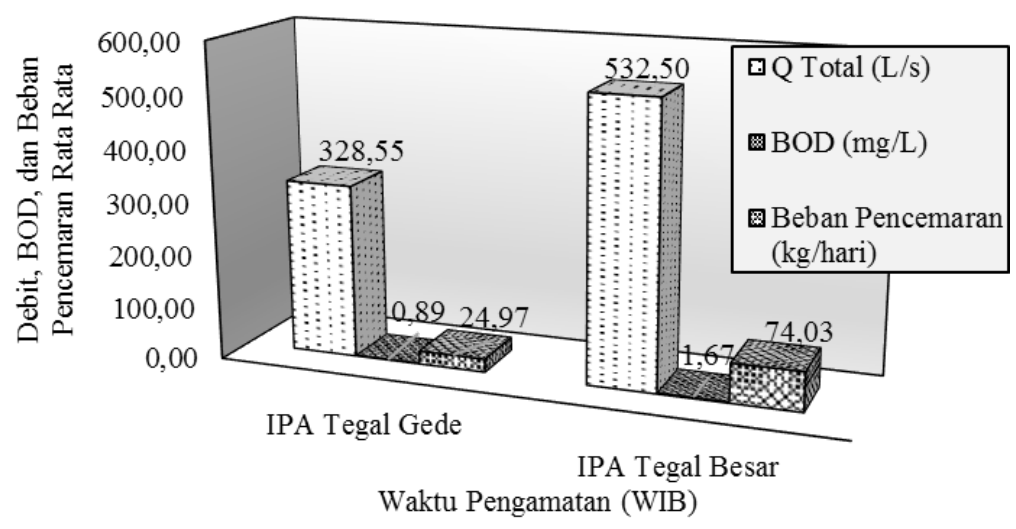

Gambar 5. Nilai rata-rata debit air, BOD, dan beban pencemaran di kedua IPA PDAM

Perbandingan kondisi beban pencemaran ratarata kedua IPA dapat dilihat pada gambar 6. Hal tersebut dikarenakan Sungai Bedadung pada titik 2 lebih sering dimanfaatkan untuk tempat pembuangan sampah dan juga letak lokasinya dekat dengan pusat Kota Jember yang padat pemukiman. Sedangkan Sungai Bedadung pada titik 1 lebih sering dimanfaatkan warga untuk mandi, mencuci dan buang air dan letak lokasinya bukan di pusat Kota Jember yang tidak padat pemukiman. Disisi lain berdasarkan gambar 1 IPA Tegal Besar terletak di downstream sehingga potensi akumulasi beban pencemaran dari aliran bagian upstream berpotensi meningkatan nilai beban pencemarannya. Kecenderungan dari kedua intake terhadap nilai BODnya, lebih rendah di pagi hari dan debit airnya relatif tinggi. Oleh sebab itu diasumsikan pengambilan dan pengolahan air baku lebih efektif dilakukan saat pagi hari. Bagi PDAM Kabupaten Jember, rekomendasi pengolahan air dioptimalkan pada pagi hari mengingat potensi beban pencemaran dari hasil pemeriksaan cenderung lebih rendah. Adapun strategi pengolahan air baku agar lebih efektif pada IPA Tegal Besar mengingat tingginya bahan organik yang terpapar pada sumber airnya, diperlukan upaya pretreatment menggunakan biofilter untuk mereduksi bahan organik mudah urai ataupun yang tidak mudah diuraikan. ${ }^{34}$ Disisi lain untuk meningkatkan hasil pengolahan air baku pada dapat melakukan kombinasi penggunaan koagulan seperti PACl dan ultrafiltrasi sebagai alternatif penanganan sekunder. Metode ini dilaporkan dapat meningkatkan kinerja koagulan hingga 21\% sehingga mampu menekan biaya operasionalnya. ${ }^{31}$
Adapun selain optimalasi pengolahan IPA oleh pihak PDAM, dilakukan pula upaya pengelolaan kualitas air sungai secara komprehensif yang melibatkan beberapa pihak. ${ }^{25,26}$ Sungai Bedadung idealnya harus memenuhi baku mutu kelas I jika akan dimanfaatkan sebagai sumber air baku. Secara umum upaya pengelolaan kualitas air terdiri atas pemtauan kualitas air dan pengedalian pencemaran. Pemantauan kualitas air yang mencakup parameter, fisika, kimia, dan biologi yang menjadi indikator kondisi sumber daya air. ${ }^{27}$ Pengendalian beban pencemaran sungai pada umumnya harus memperhatikan debit air dan konsentrasi bahan pencemar. Aplikasi IPAL pada limbah domestik dan industri menjadi salah satu strategi menurunkan konsentrasi bahan pencemar sehingga limbah tidak melebihi baku mutu yang berlaku. $^{29}$ Disisi lain diperlukan upaya konservasi pada daerah hulu DAS Bedadung guna mendukung keberlanjutan sumber daya air dari segi kuantitasnya.

\section{SIMPULAN}

Kualitas air di intake PDAM Kabupaten Jember memiliki nilai yang beragam. Secara umum kualitas air di intake Tegal Gede berdasarkan parameter fisika dan kimia air sungai tersebut tidak melebihi baku mutu kelas I menurut Peraturan Pemerintah Republik Indonesia Nomor 82 Tahun 2001 tentang Pengelolaan Kualitas Air dan Pengendalian Pencemaran Air. Baku mutu kelas I berpotensi layak dimanafaatkan sebagai sumber air baku. Namun nilai COD pada intake Tegal Besar tergolong kelas III. Oleh sebab itu kualitas air di intake tersebut tergolong kelas III meskipun parameter lainnya tergolong kelas I. Nilai beban pencemaran tertinggi di kedua titik pada hari pertama 
hingga ketiga rata-rata terjadi pada siang hari pukul 11.30 WIB, bila dilihat pada nilai rata-rata beban pencemaran pada Titik 2 lebih tinggi bila dibandingkan dengan beban pencemaran pada Titik 1 . Fakta empiris ini didukung dengan uji t dengan nilai signifikasi $\alpha=0,05$ yang menujukkan terdapat perbedaan signifikan pada nilai beban pencemaran di IPA Tegal Gede dan Tegal Besar. Bagi PDAM Kabupaten Jember, rekomendasi pengolahan air dioptimalkan pada pagi hari mengingat potensi beban pencemaran dari hasil pemeriksaan cenderung lebih rendah. Adapun strategi pengolahan air baku agar lebih efektif pada IPA Tegal Besar mengingat tingginya bahan organik yang terpapar pada sumber airnya, diperlukan upaya pretreatment menggunakan biofilter untuk mereduksi bahan organik mudah urai ataupun yang tidak mudah diuraikan. Disisi lain untuk meningkatkan hasil pengolahan air baku pada dapat melakukan kombinasi penggunaan koagulan seperti $\mathrm{PACl}$ dan ultrafiltrasi sebagai alternatif penanganan sekunder.

\section{UCAPAN TERIMA KASIH}

Terima kasih kami sampaikan kepada Lobaratorium Teknik Penngendalian dan Konservasi Lingkungan Jurusan Teknik Pertanian, Fakultas Teknologi Pertanian, Universitas Jember dalam menyediakan fasilitas pendukung dalam penyelesaian penelitian ini serta pihak-pihak yang terlibat dalam penelitian ini.

\section{DAFTAR PUSTAKA}

1. Asian Development Bank. Indonesia: country water assessment. Manila, 2016.

2. Peraturan Menteri Lingkungan Hidup Nomor 1 Tahun 2010 Tentang Tata Laksana Pengendalian Pencemaran Air. Jakarta. 2010.

3. Pusat Data dan Informasi Kementerian Lingkungan Hidup Republik Indonesia, Indeks kualitas lingkungan Indonesia tahun 2017. Jakarta. 2018.

4. Kusumawardani D. Estimasi biaya pencemaran air sungai: studi kasus pada Kali Surabaya untuk produksi air minum. Majalah Ekonomi' 2012: 116-124.

5. Pradana HA, Novita E, Wahyuningsih S, Pamungkas R. Analysis of deoxygenation and reoxygenation rate in the Indonesia River: a case study: Bedadung River East Java. in IOP Conf. Ser: Earth Environ. Sci, 2019, 243.

6. Aziza SN, Wahyuningsih S, Novita E. Beban pencemaran Kali Jompo di Kecamatan Patrang Kaliwates Kabupaten Jember. Jurnal Agroteknologi Volume 12(1): 100-106. 2018.

7. Peraturan Pemerintah Republik Indonesia Nomor 82 Tahun 2001 tentang Pengelolaan Kualitas Air dan Pengendalian Pencemaran. Jakarta. 2001.

8. Peraturan Daerah Provinsi Jawa Timur Nomor 02 Tahun 2008 Tentang Pengelolaan Kualitas Air dan Pengendalian Pencemaran Air. 2008.
9. Nurjanah U. Studi keanekaragaman makrobentos sebagai bioindikator kualitas air sungai Bedadung Jember. Prosiding Seminar Nasional Biologi, 2016, p. 202-209.

10. Dinas Lingkungan Hidup Provinsi Jawa Timur, Dokumen informasi kerja pengelolaan lingkungan hidup daerah Provinsi Jawa Timur tahun 2016.

11. Munandar K, Eurika N. Keanekaragaman ikan yang bernilai ekonomi dan kandungan logam berat pb dan cd pada Ikan Sapu-Sapu di Sungai Bedadung Jember. in Proceeding Biology Education Conference 2016: 717-722.

12. Vade KK, Wang J, Cao L, Yuan T, McCarthy AJ, Sejar R. Assesment of water quality and identification of pollution risk locations in Tiaxi River (Taihu Watershed). Water, 2018, 10(183):1-18.

13. Wardiani FE, Wimbaningrum R, Setiawan R. Hubungan antara tipe penggunaan lahan dengan kualitas air di Sungai Rembangan, Kabupaten Jember. Jurnal Ilmu Dasar, 2019, 20(2): 11-122.

14. Bu H, Meng W, Zhang Y, Wan J. Relationships between land use patterns and water quality in the Taizi River Basin, China. Ecol. Indic, 2014, 41: 189-197

15. Rejekiningrum P. Dampak perubahan iklim terhadap sumberdaya air: identifikasi, simulasi, dan rencana aksi. Jurnal Sumberdaya Lahan, 2014, 8(1): 1-15.

16. Shi P, Zhang Y, Li Z, Li P, Xu G. Influence of land use and land cover patterns on seasonal water quality at multi-spatial scales. Catena Elsevier B.V, 2017, 151: 182-190.

17. Peraturan Menteri Lingkungan Hidup Nomor 110 Tahun 2003 Tentang Pedoman Penetapan Daya Tampung Beban Pencemaran Air pada Sumber Air. Jakarta. 2003.

18. Peraturan Menteri Lingkungan Hidup Nomor 115 Tahun 2003 Tentang Pedoman Penentuan Status Mutu Air. Jakrta, 2003.

19. Saraswati SP, Sunyoto, Kironoto BA. Kajian bentuk dan sensitivitas rumus indeks PI, stroret, come untuk penentuan status mutu perairan sungai tropis di Indonesia. Jurnal Manusia dan Lingkungan, 2014, 21(2): 129-142.

20. Effendi H. River water qualit preliminariy rapid assesment using pollution index. Procedia Environ. Sci. Volume 33: 562-567. 2016.

21. Sasongko EB, Widyastuti E, Priyono R. Kajian kualitas air dan penggunaan sumur gali oleh masyarakat di sekitar Sungai Kaliyasa Kabupaten Cilacap. Jurnal Ilmu Lingkungan, 2014, 12(2): 72-82.

22. Sulaksono A, Effendi H, Kurniawan B. Kajian beban pencemaran limbah cair industri kecil menengah batik klaster Trusmi Kabupaten Cirebon. Jurnal Pengelolaan Sumberdaya Alam dan Lingkungan, 2015, 5(1): 17-24.

23. Widodo, Kasam, Ribut L, Ike A. Strategi 
penurunan pencemaran limbah domestik di Sungai Code DIY. Jurnal Sains dan Teknologi Lingkungan, 2013, 5(1): 36-47.

24. Evans AEV, Hanjra MA, Jiang Y, Qadir M, Drechsel P. Water quality: assesment of the current situation in Asia. Water Resources Development, 2012, 28(2): 195-265.

25. Indrawati D. Upaya pengendalian pencemaran sungai yang diakibatkan oleh sampah. TJL, 2011, 5(6): 193-200.

26. Pohan DAS, Budiyono, Syafrudin. Analisis kualitas air sungai guna menetukan peruntukannya ditinjau dari aspek lingkungan. Jurnal Ilmu Lingkungan, 2016, 14(2): 63-71.

27. Trisnaini I, Kumalasari TN, Utama F. Identifikasi habitat fisik sungai dan keragaman biotilitik sebagai indikator pencemaran air Sungai Musi Kota Palembang. Jurnal Kesehatan Lingkungan Indonesia, 2018, 17(1): 1-8.

28. Sari SYI, Sunjaya DK, Shimizu-Furusawa C, Watanabe H, Raksanagara S. Water sources quality in urban slum settlement along the contaminated River Basin in Indonesia: apllication of quantitative microbial risk assessment. Journal of Environmental Public Helath, 2018, 7.

29. Halmat A, Guidoum A, Koulala I. Status and trend of water quality in the Tafna Catchment: a comparative study using water quality indices. Journal of Water Reuse and Desalination, 2016, 7(2): 228-245.

30. Liu X, Teubner K, Chen Y. Water quality characteristics of Poyang Lake, China, in response to change in water level. Hydrology Research, 2016, 47(51): 239-248.

31. Arhin SG, Banadda N, Komakech AJ, Pronk W,
Marks SJ. Application of hybrid coagulationultrafiltration for decentralized dringking water treatment: impact on flux, water quality, and cost. Water Supply, 2019: 1-9.

32. Rajasingham A, Leso M, Ombeki S, Ayers T, Quick R. Water treanment and handwashing practices in rural Kenya health care facilities and households six years after the instalation of portable water stations and hygiene traning. Journal of Water and Health, 2018, 16(2): 263273.

33. Yudo S, Said NI. Status kualitas air Sungai Ciliwung di Wilayah DKI Jakarta studi kasus: pemasangan stasiun online monitoring kualitas air di segmen Kelapa Dua-Masjid Istiqlal. Jurnal Teknologi Lingkungan, 2018, 20(1): 19-28.

34. Yudo S, Said NI. Kondisi kualitas air Sungai Surabaya studi kasus: peningkatan kualitas air baku PDAM Surabaya. Jurnal Teknologi Lingkungan, 2019, 20(1): 19-28.

35. Ardiyanto P, Yauntari MGC. Analisis limbah laundry informal dengan tingkat pencemaran lingkungan di Kelurahan Muktiharjo Kidul Kecamatan Pendurungan Semarang. Jukung Jurnal Teknik Lingkungan, 2016, 2(1): 1-12.

36. Pangestu R, Riani E, Effendi H. Estimasi beban pencemaran point souce dan limbah domestik di Sungai Kalibaru Timur Provinsi DKI Jakarta, Indonesia. Jurnal Pengelolaan Sumberdaya Alam dan Lingkungan, 2017, 7(3): 219-226.

37. Li S, Chen X, Singh VP, He Y, Bae X. An improved index for water quality evaluation in an estuary region: a case study in the Eastern Pearl River Delta, China. Water Policy, 2019, 21: 310-325. 